\title{
Многолетняя динамика пляжей и берегов Каламитского залива Крыма
}

\author{
И.В. Агаркова-Ля ${ }^{1 凶}$, А.М. Лях ${ }^{2}$ \\ ${ }^{1}$ Институт природно-технических систем, Российская Федерация \\ (299011, г. Севастополь, ул. Ленина, 28)
}
${ }^{2}$ ФГБУН Федеральный исследовательский иентр «Институт биологии южных морей имени А.О. Ковалевского РАН», Российская Федераџия
(299011, г. Севастополь, просп. Нахимова, 2)

\begin{abstract}
Аннотация: Цель статьи - охарактеризовать динамику пляжей и берегов Каламитского залива по данным многолетних наблюдений за период XX - нач. XXI вв.

Meтоды. Для анализа доступной информации использовались сравнительно-географический, сравнительно-исторический и картографический методы исследования. При проведении береговых работ применялся комплекс полевых методов: наблюдения на ключевых участках, инструментальные и полуинструментальные замеры, фотометод.

Результаты и обсуждение. Рассмотрены изменения ширины пляжей в границах города Евпатория с начала XX века; на других участках залива с середины 80-ых годов XX века. Охарактеризованы скорости отступания берегов с 40-ых годов XX века. Указаны антропогенные и природные факторы, определяющие современную береговую динамику.

Заключение. За рассматриваемый период ширина пляжей на разных участках Каламитского залива сократилась в 2-4 раза, а на некоторых из них пляжи исчезли совсем. Средняя скорость размыва берегов за последние 100 лет составила 1,3 м·год ${ }^{-1}$, максимальная $-7,8$ м.год ${ }^{-1}$. Эти процессы сопровождаются истощением запасов обломочного материала на пляже и подводном склоне, размывом отложений бенча, разрушением береговых построек. Данная ситуация вызвана дефицитом пляжеобразующего материала в береговой зоне, возникшим вследствие интенсивного хозяйствования на побережье: карьерные разработки, строительство водохранилищ, гидротехнических и берегозащитных сооружений. Сопутствующую роль в деградации пляжей играют природные факторы: повышение уровня моря, опускание побережья, литология берегов, истирание наносов, эоловый вынос, изменения ветро-волновой обстановки, активизация экстремальных штормов.
\end{abstract}

Ключевые слова: сокращение ширины пляжей, размыв берегов и бенча, отступание берегов, дефицит обломочного материала, хозяйственная деятельность.

Источник финансирования: Работа выполнена в рамках госзадания ИПТС (№ госрегистрации АААА-А19-119031490078-9) и госзадания ФИЦ ИнБЮМ (гос. регистрационный № AААA-A18-118020890074-2).

Для цитирования: Агаркова-Лях И. В., Лях А. М. Многолетняя динамика пляжей и берегов Каламитского залива Крыма // Вестник Воронежского государственного университета. Серия География. Геоэкология, 2021, № 3, с. 41-51. DOI: https://doi.org/10.17308/geo.2021.3/3599

\section{ВВЕДЕНИЕ}

Пляжи Каламитского залива - основной рекреационный ресурс Западного Крыма. С 30-х годов XX в. на отдельных участках залива началось поступательное уменьшение ширины пляжей, а в 80-е годы оно сменилось их деградацией практически по всей береговой линии. Сокращение ширины пляжей и отступание берегов Каламитского залива сегодня представляет серьезную региональную проблему.

Цель статьи - охарактеризовать динамику пляжей и берегов Каламитского залива по данным многолетних наблюдений на протяжении XX - нач. XXI вв.

\footnotetext{
(C) Агаркова-Лях И.В., Лях А. М., 2021

$\square$ Агаркова-Лях Ирина Владимировна, e-mail: iva_crimea@mail.ru
}

cc) (i) Контент доступен под лицензией Creative Commons Attribution 4.0 License. 


\section{МАТЕРИАЛЫ И МЕТОДЫ}

Основными методами обработки опубликованной и фондовой информации выступили: сравнительно-географический, сравнительно-исторический и картографический. При проведении полевых исследований применялись методы наблюдения за пляжами и берегами на ключевых участках, инструментальных и полуинструментальных замеров морфометрических характеристик берегов и пляжей, фотофиксация береговой обстановки. Ключевым районом мониторинга стал участок побережья на Сакской пересыпи между детским оздоровительным лагерем (ДОЛ) «Звездный» им. космонавта Г. Титова и пос. Прибрежное.

В статье использованы фондовые материалы Института минеральных ресурсов (ИМР), Крымской государственной гидрогеологической экспедиции (КГГЭ), Ялтинской инженерно-геологической партии (ЯИГП), Крымского республиканского противооползневого управления (КРПУ); результаты собственных маршрутно-полевых работ за период с 1998 по 2017 год.

\section{РЕЗУЛЬТАТЫ И ОБСУЖДЕНИЕ}

Первые работы по изучению берегов и пляжей Каламитского залива были начаты под руководством Зенковича В.П. в 40-е годы XX в. Позднее их дополнили исследования эволюции акватории залива Невесского Е.Н., гранулометрического и вещественного состава пляжей, динамики береговых процессов $[13,14,19,20]$. Во второй половине XX в. широкие изыскания на берегах и пляжах залива вели крупные научно-производственные организации Крыма.

В 2000-е годы был существенно расширен спектр наблюдений в Каламитском заливе, охвативших изучение ландшафтной структуры и последствий антропогенного преобразования береговой зоны $[2,3,9,11,15,22]$, анализ литодинамических процессов на подводном склоне и гранулометрического состава пляжных отложений $[8,21,22,23,24]$, вопросы берегопользования и берегозащиты $[3,6,7,10,15]$.

Каламитский залив расположен у Западного берега Крыма и ограничен на севере м. Евпаторийский, на юге - м. Лукулл (рис. 1). Общая протяженность его берегов составляет около 66 км. Ранее берега залива являлись примером абразионно-аккумулятивной пары (по Зенковичу В.П.), состоящей из двух различных по генезису участков: северного аккумулятивного (от м. Евпаторийский до оз. Кызыл-Яр) и южного абразионного (от оз. Кызыл-Яр до м. Лукулл), связанных вещественным обменом в единую литодинамическую систему.
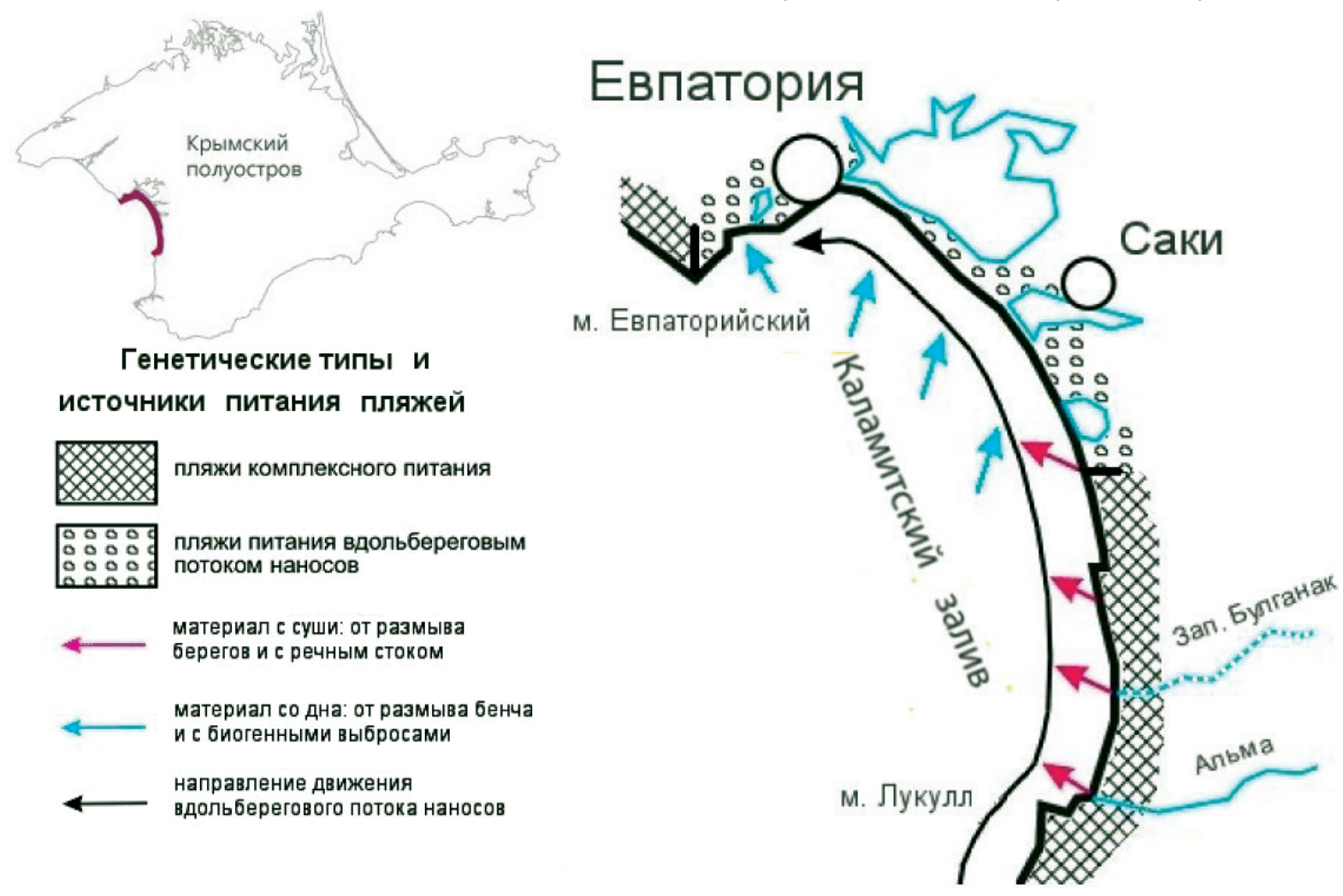

Puc. 1. Источники питания и генетические типы пляжей Каламитского залива (составлено авторами) [Fig. 1. Genetic types of beaches and sources of beaches feeding (compiled according to)] 
Пляжи южного абразионного участка образовались за счет материала твердого стока рек Западный Булганак и Альма, продуктов размыва берегов и подводного склона, биогенных выносов и материала вдольберегового потока (рис. 1). Пляжи прислонены к береговым откосам и сложены песчаными, глыбово-песчаными и гравийно-галечниковыми отложениями.

Северный аккумулятивный участок сформирован, главным образом, транспортируемым с юга материалом вдольберегового потока наносов, направленного от устья реки Бельбек к Евпатории и включающего твердый сток рек Юго-Западного и Западного Крыма, донные выбросы, продукты размыва берегов и бенчей (рис. 1). Они относятся к пляжам полного профиля и имеют песчаный, гравийно-песчаный и гравийный гранулометрический состав.

Рассмотрим изменения ширины пляжей на разных участках Каламитского залива в течение XX - начало XXI вв. при движении с юга на север от м. Лукулл к м. Евпаторийский.

В середине 80-х годов ХХ в. в устье р. Альмы существовал естественный пляж шириной 8,0-10,0 м, а у с. Песчаное - искусственный пляж такой же ширины. Уже тогда наблюдающееся здесь сокращение пляжей потребовало строительства берегозащитных сооружений. К 1990 году на берегу появились пятнадцать бун длиной от 50,0 до 85,0 м, расположенные на расстоянии 50,0-500,0 м друг от друга [7]. Межбунное пространство заполнили щебнем. Клиф севернее группы бун был срезан и террасирован. К 1994 году здесь построили откосно-ступенчатую волногасящую набережную протяженностью почти 850,0 м. Сооруженный комплекс просуществовал недолго. Уже в 2005 году были полностью или частично разрушены берегоукрепительные сооружения на пляжах сельсовета и пансионата «Волна», пансионатов «Радуга» и «Лукоморье».

Пляжи севернее с. Песчаное и у с. Береговое в середине 80 -х годов XX в. имели ширину $5,0-8,0$ м, а к северу от с. Береговое - 10,0-15,0 метров. В это время в устье реки Западный Булганак (с. Береговое) была возведена откосно-ступенчатая волногасящая набережная длиной около 400,0 метров. Спустя 20 лет, пляжи у с. Береговое сократились до 4,0-7,0 м, а расстояние от бровки берегового обрыва до ближайших построек оздоровительно-спортивного комплекса «им. Шевченко» составило всего 2,5-5,0 метров. Начавшиеся в 2013 году работы по восстановлению берегоу- крепительных сооружений в с. Береговое до настоящего времени не завершены [7].

Катастрофическая ситуация с деградацией пляжей у пгт. Николаевка возникла в конце 70-х годов XX в., угрожая функционированию множества рекреационных объектов. В ответ на это, в 1981-1982 годах в южной и северной частях пгт. Николаевка началось строительство откосно-ступенчатой волногасящей набережной, сооруженной к 1990 году на 1,5 км вдоль побережья.

В южной части пгт. Николаевка в середине 80 -х годов пляж был шириной около 30,0 метров, но уже через десять лет после постройки набережной, пляжи резко сократились, а в ряде мест полностью исчезли (пансионаты «Большевик», «Горняк», «Южный», «Изумруд»).

В 2006-2008 годах на южном участке пгт. Николаевка были построены шесть поперечных бун для формирования искусственных пляжей и защиты оставшихся к этому времени участков набережной [6]. Строительство бун способствовало увеличению пляжей южнее бун и их стремительная деградация севернее, сопровождаемая разрушением берегозащитных сооружений.

В центральной части пгт. Николаевка в 1990 году ширина пляжа, защищенного откосно-ступенчатой набережной, составляла 23,0-34,0 м, а к 2005 году она сократилась до 10,0-18,0 м у пансионата «Энергетик», базы отдыха (БО) «Скиф$88 »$, спасательной станции и до 3,0-5,0 м у пансионатов «Полимер», «Солнечный», «Лучезарный»).

Ширина пляжа севернее пгт. Николаевка стабилизировалась лишь после возведения в 1992 году на мысе у населенного пункта двух бун. В итоге в северной предмысовой части поселка с конца 90-х годов стал отмечаться прирост пляжного материала между пансионатами «Солнышко» и «Полет».На расстоянии около 1,5 км к югу от мыса ширина пляжа стабилизировалась до 25,035,0 метров. По состоянию на 2005 год, этот участок, в целом, оставался устойчивым, с шириной пляжа 22,0-30,0 м и его сезонными изменениями в пределах 5,0-7,0 метров.

В середине 80-х годов пляж к югу от пересыпи 03. Богайлы имел ширину 18,0 м. Между озерами Богайлы и Кызыл-Яр ширина пляжа составляла 7,0-12,0 м, а в районе Красной Горки 10,0 метров. В те же годы ширина Кызыл-Ярской пересыпи в ее южной части была 200,0 м. После строительства в 1979-1982 годах в северной части Кызыл-Ярской пересыпи гидротехнического сооружения, перед ним стал нарастать по нашим 
данным пляж со средней скоростью 7,5 м·год ${ }^{-1}$. В начале 2000-х годов южная часть Кызыл-Ярской пересыпи сократилась в 1,5 раза, а береговая линия в ее северной части выдвинулась в море на 120,0 м, на длину гидротехнического сооружения.

Аналогичные явления сокращения пляжей наблюдаются в южной и средней частях Сакской пересыпи между ДОЛ «Звездный» и детским оздоровительным центром (ДОЦ) «Прибрежный». По результатам наших исследований в начале 80-ых годов у ДОЛ «Звездный» и БО «Уют» были пляжи шириной до 60,0 м, от которых сегодня остались жалкие «крохи» - 10,0-15,0 метров. Формирующийся здесь уступ размыва имеет высоту от 0,1 до 2,0 м с постоянным его смещением в сторону суши. Пляж в северной части Сакской пересыпи у ДОЦ «Прибрежный» относительно стабилен. Его изменения с середины 80-х годов лежат в пределах от $-3,0$ до $+5,0$ м. Ширина пляжей севернее ДОЦ «Прибрежный», у БО «Прибой» и ДОЛ «Голубая волна», практически не изменилась за исследуемый период и составляет более 50,0 м.

На пересыпи озера Сасык-Сиваш средняя ширина пляжей в середине 80-х годах составляла от 30,0 до 50,0 м. Максимальных величин 50,0-100,0 м в этот период достигали пляжи полного профиля напротив пос. Прибрежное, где береговая линия меняет свое направление и происходит аккумуляция материала вдольберегового потока наносов.

В северной части пересыпи оз. Сасык-Сиваш берег Каламитского залива поворачивает к западу, образуя Евпаторийскую бухту, протягивающуюся до м. Карантинный.

В конце 50-х - начале 80-х годов ширина евпаторийских пляжей на восточной окраине города в районе частной застройки на улице Симферопольской была 30,0-50,0 м. После затопления этой территории во время сильнейшего шторма ноября 1981 года началось уничтожение морем части данной улицы вместе с набережной. В настоящее время попытки отдельных собственников защитить свои дома от разрушения привели к тому, что приморская зона представляет собой «завалы» из камня-ракушечника, разбитых ступеней, бетонных плит.

В 1968-1972 годах западнее улицы Симферопольской, в исторической части города, была построена набережная им. В. Терешковой длиной 1,8 км в виде бетонной стенки с фасонным волноотбойником, и выдвинута в море на 30,0-50,0 м. После этой реконструкции пляжи здесь полностью исчезли [6].
До 50-х годов XX в. на м. Карантинный и прилегающих участках был широкий пляж полного профиля, сужавшийся к востоку до 10,0-20,0 м. В конце 70-х годов на мысу построили мол Евпаторийского морского торгового порта длиной 200,0 м. С восточной стороны образовалась обширная отмель, а с западной (в районе набережной им. М. Горького) берег начал активно отступать. Это строительство «стоило» городским пляжам потери до 50,0 м их ширины [6]. После появления мола, пляжи между м. Карантинный и м. Евпаторийский устойчиво деградируют.

$\mathrm{B}$ начале XX в. ширина пляжей у современной набережной им. М. Горького составляла 21,0-85,0 м, а в 2005 году осталось только 15,0-35,0 м. У нынешнего парка им. Фрунзе (пансионат «Золотой берег»), ширина пляжа в начале XX в. была 50,0-80,0 м, в середине 80-х годов - 30,0-40,0 м, а в 2005 году - лишь 6,0-15,0 м. За 90 лет, с 1915 по 2006 год ширина пляжа в районе современного санатория «Орленок» сократилась более чем в два раза. По подсчетам [6], в центральной части Евпатории пляжи полностью отсутствуют на протяжении 3,0 км, а еще на протяжении 1,5 км они существенно уменьшились.

Ширина пересыпи оз. Мойнаки сократилась с 125,0-150,0 м в 1989 году до 90,0-100,0 м в 2005. Активное отступание берегов подтверждают формирующиеся на пляжах пансионатов «Планета», «Магнат», «Алмазный» и «Россия» уступы размыва высотой до 0,8 м. На некоторых пляжах наносы практически полностью смыты, а подстилающие их суглинки обнажены.

На пляжах Каламитского залива в конце 80-х годов наибольшие запасы отложений были cocpeдоточены на аккумулятивных пересыпях соленых озер (Богайлы, Кызыл-Яр, Сакского, Сасык-Сиваш) и в зоне разгрузки вдоль берегового потока наносов (вершина залива), а их средний удельный объем возрастал с юга на север (рис. 2). Так, в южной части залива между с. Песчаное и пгт. Николаевка средний удельный объем пляжевых наносов составлял 7,4-12,0 м³ погон.м-1, увеличиваясь к пересыпи оз. Богайлы и пгт. Ново-Федоровка до 33,9-42,0 м м $^{3}$ погон.м ${ }^{-1}$. В вершине залива, на Сасык-Сивашской пересыпи, происходила разгрузка материала вдольберегового потока наносов и средний удельный объем их достигал своего максимума - 85,0 м³ ппого.м-1 рийских пляжах объем наносов сокращался в 3-5 раз, изменяясь от $17,6 \mathrm{~m}^{3} \cdot$ погон. $\mathrm{M}^{-1}$ у м. Карантинный до 28,0 м $^{3} \cdot$ погон.м. ${ }^{-1}$ у м. Евпаторийский (рис. 2). Если сравнить коэффициенты вариации удельного объема пляжевых наносов, то наиболее динамичными были 
пляжи у м. Карантинный и пгт. Николаевка (36,4\% и $25,7 \%$ соответственно). Самый устойчивый пляж на пересыпи оз. Сасык-Сиваш (3,5\%). На пяти из семи полигонов происходило незначительное среднегодовое уменьшение ширины пляжей от 0,7 до 3,6 м.

Таким образом, с 80-ых годов XX в. до настоящего времени пляжи Каламитского залива катастрофически сокращаются от м. Лукулл до Евпатории, за исключением стабильных участков и районов гидротехнического строительства с нарушенным естественным режимом литодинамики. Средней ширины пляжей в 5,0-10,0 м недостаточно для гашения энергии морского волнения, вследствие чего их берега размываются и отступают.

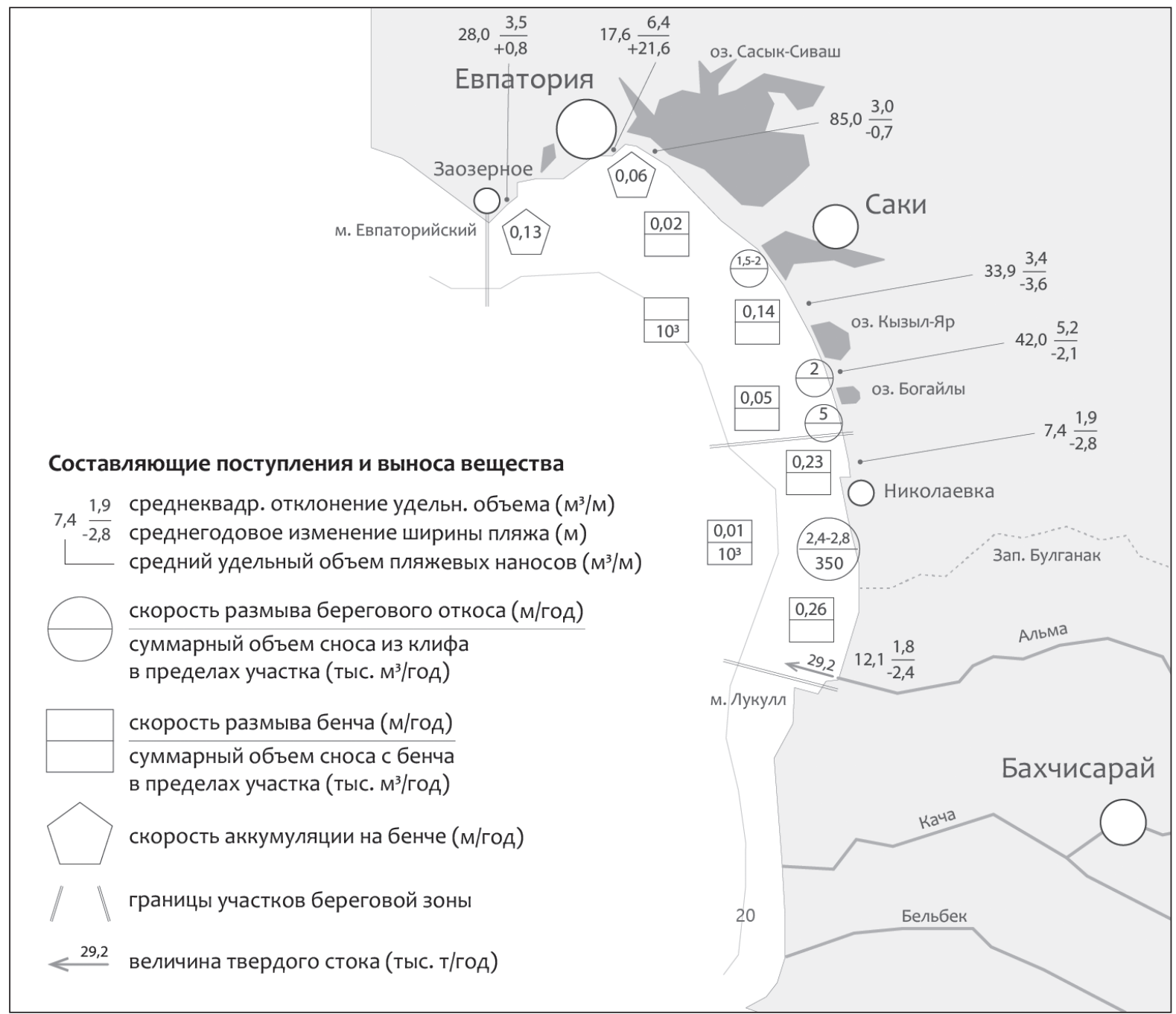

Рис. 2. Количественные показатели динамики береговой зоны Каламитского залива (составлено по данным [14, 20] с дополнениями авторов)

[Fig. 2. Dynamics of the coastal zone of the Kalamitsky Bay (compiled according to [14])]

Размыв - доминирующий береговой процесс в Каламитском заливе. Он основной поставщик обломочного материала в береговую зону. За последние 100 лет средняя скорость размыва берегов залива составила $1,3 \mathrm{м} \cdot$ год $^{-1}$, максимальная 7,8 м.год ${ }^{-1}$. Темпы отступания берегов разнятся из года в год и в течение года. Рост скоростей размыва отмечается в годы активизации штормов, а в сезонном ходе приурочен к периоду с ноября по март, когда увеличивается ветро-волновая деятельность.
Усилению размыва берегов способствует и повышение уровня моря при нагонах воды.

Максимальные скорости размыва отмечены на абразионном участке Каламитского залива. Так, в устье Альмы, у сел Песчаное и Береговое скорости размыва составляют 3,0 м.год ${ }^{-1}$. Севернее пгт. Николаевка берег отступает со скоростью 6,0 м.год ${ }^{-1}$; на участках бронирования глинистых берегов галечниковыми конгломератами она снижается до 0,6-1,0 м.год ${ }^{-1}$. 
Побережье между м. Лукулл и окончанием пересыпи оз. Богайлы, а также участок Красная Горка разрушаются со скоростью 2,0-2,8 м•год ${ }^{-1}$, а южная часть пересыпей озер Кызыл-Яр и Богайлы отступает со скоростью 5,0 м.год ${ }^{-1}$. Скорость размыва участка между пгт. Николаевка и оз. Кызыл-Яр за период 1940-1973 годов составила 1,46 м.год-1.

Участок берега севернее пересыпи оз. Богайлы у БО «Волна» (с. Фрунзе) отступил с 1994 по 2005 год на 15,0 метров. За это время были полностью разрушены ангар и лодочный причал базы, а к ее жилым корпусам бровка берегового откоса приблизились на 12,0 метров.

На аккумулятивном участке залива скорости размыва существенно ниже. В районе Сакской пересыпи Дзенс-Литовский А.И. и Зенкович В.П. указывали на отступание берега в том же темпе, что и абразионный глинистый откос у оз. Кызыл-Яр. С 1941 по 1963 год ширина пляжа в южной части Сакской пересыпи сократилась на 47,0 м, а среднегодовая скорость ее размыва составила 2,1 м.год ${ }^{-1}$. Подсчеты Шуйского Ю. Д. в 70-е годы установили скорости размыва для Сакского участка в 1,0 м'год ${ }^{-1}[19]$. В период строительства гидротехнического сооружения у оз. Кызыл-Яр (1979-1982) размыв Сакской пересыпи достигал 2,6 м'год ${ }^{-1}$.

Общее отступание береговой линии Сакской пересыпи с середины 80-х годов до 2005 года у ДОЛ «Звездный» составило 31,0 м, у БО «Уют» - 24,0-33,0 м, а на всем участке от ДОЛ «Звездный» до оздоровительного комплекса «Парус» 18,0 метров. По результатам наших наблюдений максимальная скорость размыва Сакской пересыпи у ДОЛ «Звездный» за период 1984-1998 годов сохранялась на уровне 3,76 м.год ${ }^{-1}$. Средняя скорость смещения бровки берегового уступа на этом участке за периоды 1983-2005 годы и 1998-2005 годы были равны соответственно 1,5 и 1,8-2,0 м.год ${ }^{-1}$ $[2,22]$. В течение этого времени здесь полностью разрушена построенная в 1986 году набережная с наклонной подпорной стенкой; разрушены морем до десяти летних жилых домиков БО «Уют».

В 70-е годы размыв на Евпаторийском участке достигал 3,75 м.год ${ }^{-1}$ [19]. Средние скорости размыва пляжей Евпатории на разных отрезках побережья колеблются от 1,0 до 2,0 м.год . $^{-1}$

Вместе с отступанием берегов, происходит донная абразия и размыв отложений на подводном склоне. Ее скорости уменьшаются с юга на север залива от 0,23-0,26 м'год ${ }^{-1}$ до 0,02 м'год ${ }^{-1}$ (рис. 2). Лишь у м. Карантинный и м. Евпаторийский наблюдается слабая донная аккумуляция со скоростями 0,06 и 0,13 м год $^{-1}$ соответственно, связанная с блокировкой материала у мола Евпаторийского порта и разгрузкой вдольбереговых наносов, движущихся от м. Урет и из южной части Каламитского залива.

Сложившаяся в Каламитском заливе береговая обстановка обусловлена чрезвычайно низким количеством поступающего в береговую зону обломочного материала. В условиях катастрофического снижения твердого стока рек и низкой продукции ракуши, основным источником пляжеобразующего материала в береговой зоне является размыв береговых откосов и подводного берегового склона, удельная величина наносов которых составляет соответственно $2,7 \mathrm{~m}^{3} / \mathrm{M}^{-1}$ год ${ }^{-1}$ и $1,7 \mathrm{~m}^{3} / \mathrm{M}^{-1}$ год-1 [18]. Суммарно они дают около $4,4 \mathrm{~m}^{3} / \mathrm{M}^{-1} \cdot$ год $^{-1}$ наносов в среднем за многолетний период. Формирующийся в Каламитском заливе ненасыщенный поток наносов мощностью 65,0 тыс. $\mathrm{M}^{3} \cdot$ год $^{-1}$ полностью разгружается на дно Евпаторийской бухты, оставив без подпитки берега и пляжи северной части залива [18]. В результате, нехватка обломочного материала в береговой зоне компенсируется сокращением пляжей и отступанием берегов, размывом отложений подводного склона и реликтовых гравийно-галечных глубоководных валов, переуглублением приурезовой зоны.

Причины современного дефицита наносов заключаются в неразумной хозяйственной деятельности $[1,2,3,5$,$] . Кратко обратим внимание$ на основные техногенные причины.

1. Карьеры по добыче песка и гальки: у пос. Прибрежный в северной части залива (с 20-ых30-ых гг. XX в. - на пляжах; в 1952-1972 гг. на глубинах 2,5-5,0 м); на пляжах у сел Береговое и Песчаное в южной части залива (до 1985 г.), где формируется естественный вдольбереговой поток наносов; на пересыпи оз. Кызыл-Яр и в Евпаторийской бухте (после 1985 г.) [15]. В настоящее время добыча песка с пляжей и пересыпей запрещена, но имеются факты его несанкционированного отбора.

2. Создание водохранилищ на реках Западного и Юго-Западного Крыма (в 20-е - 30-е годы на Альме и Каче; в 60-е - 80-е годы - на Бельбеке, Альме и Каче). В конце XX в. годовой твердый сток р. Альмы составлял 29,21 тыс. т., Качи - 61,67 тыс. т., Бельбека - 65,32 тыс. т. По самым скромным нашим оценкам, количество влекомых наносов, поставляемых этими реками, сократилось в настоящее время не менее чем в 2 раза.

3. Гидротехнические сооружения, построенные в конце 70-х - начале 80-х годов у оз. Кы- 
зыл-Яр, на м. Карантинный и др., перехватывают вдольбереговой поток наносов.

4. Берегозащитные сооружения (буны, пирсы, откосно-ступенчатые волногасящие набережные, берегозащитные стены и т.д.) и иные мероприятия (срезка и террасирование склонов и пр.) активно применялись всю вторую половину $\mathrm{XX}$ в. Использование бун приводит к «низовому» размыву пляжей, а изъятие береговых откосов из вещественного обмена с морем снижает количество вещества, поступающего в береговую зону.

5. Нарастающее загрязнение морской воды и донных грунтов (его «пик» пришелся на 80-е - 90-е годы) сокращает численность и продуктивность морских гидробионтов, снижает вклад биогенного материала в формирование гранулометрического и вещественного состава пляжей [5].

Перечисленные выше факторы снизили объемы пляжеобразующего материала во вдольбереговом потоке наносов, обострив проблему питания и устойчивого развития аккумулятивных форм северной части Каламитского залива.

Несмотря на ведущее значение хозяйственной деятельности в нарушении баланса обломочного материала на исследуемом побережье, нельзя не отметить вклад природных факторов, играющих свою роль в деградации пляжей и отступании берегов.

1. Тектоническое погружение Альминской синеклизы, в пределах которой располагается большая часть Каламитского залива, со средней скоростью 2,5-3,0 мм/год.

2. Повышение уровня Черного моря на 15,0 см за период с конца 40-х годов. Этот процесс коррелируется с отступанием аккумулятивных берегов: при повышении уровня моря на 1,0 см они отступают на 30,0 см [15]. Исходя из этой взаимосвязи, берега Каламитского залива отступили за последние 70 лет на 4,5 м.

3. Слабая устойчивость берегов к размыву: северный участок сложен рыхлыми морскими четвертичными отложениями из песка, ракуши, гравия и гальки, относящихся к категории очень податливых пород; южный - красно-бурыми плиоцен-четвертичными глинами, податливыми к размыву.

4. Усиление циклонической и штормовой активности на Черном море в конце XX - начале XXI вв. [12]. Примером тому являются шторма ноября 1981 и 1992 гг., января 2000 г., февраля 2004 г., ноября 2007 г., февраля 2011 и 2012 гг., октября 2014 г., декабря 2016 г. и др. За период с середины 80-х годов и до начала XXI в. почти на 10\% выросла повторяемость штормов от ветров юго-западного и южного направлений, наиболее разрушительных для пляжей Каламитского залива [2].

5. Общее снижение запасов пляжевых накоплений за многолетний период из-за истирания и измельчения гравийно-галечных и песчаных пляжных отложений, их безвозвратного выноса за пределы береговой зоны с эоловыми и волновыми процессами в надводные и подводные очаги аккумуляции.

Отрицательная динамика пляжей и берегов Каламитского залива ставит приоритетную задачу для всего региона - проведение работ по защите и сохранению пляжей. Однако на данный момент реализация берегозащитных проектов в гг. Евпатория и Саки в рамках выполнения Федеральной целевой программы терпит крах.

Первый проект в Евпатории по берегоукреплению и реконструкции набережной им. В. Терешковой, протяженностью около 1,5 км, начался в конце 2017 года и предусматривал отсыпку пляжей, строительство берегозащитных гидротехнических сооружений и двух волноломов для удержания пляжей. В его реализацию было заложено 770 млн. руб., а открытие новой набережной намечалось на конец 2019 года. Но совместная проверка федерального казначейства и заказчика в 2019 году показала, что выполненную часть проекта подрядчик сделал некачественно и в нарушение ранее утвержденного проекта. По итогам проверки контракт с подрядчиком был разорван, а строительство остановлено. В июле 2020 г. назначен новый подрядчик.

По второму проекту, начатому в 2019 году, планировалось строительство на Сакской пересыпи набережной длиной более 5,5 км и комплекса гидротехнических сооружений из двух бун на сваях и десяти подводных волноломов, расширения пляжа за счет его отсыпки щебнем толщиной 80,0-100,0 мм. Проект вызвал много вопросов и критики еще на этапе представления общественности. Общая стоимость работ по проекту оценивалась в 1,147 млрд. руб., а их окончание ожидалось в 2021 году. Однако в феврале 2020 года строительство было приостановлено по евпаторийскому сценарию: изза невыполнения условий договора и несоблюдения графика работ подрядчиком. На данный момент власти г. Саки планируют доработать первоначальный проект набережной с учетом пожеланий местных жителей, найти нового подрядчика для проведения работ и открыть набережную к середине 2022 года.

\section{ЗАКЛЮЧЕНИЕ}

В первой половине XX в. берега Каламитского залива представляли собой единую абразион- 
но-аккумулятивную пару, в которой абразионные берега поставляли обломочный материал для нарастания аккумулятивных.

В настоящее время аккумулятивные берега залива активно отступают, практически, на всем протяжении, исключая участки гидротехнического строительства с нарушенным естественным литодинамическим режимом.

Причиной данной ситуации является резкое сокращение объемов поступления в береговую зону обломочного материала из-за усиления с 20-ых30-х годах хозяйственной деятельности в заливе, выраженной зарегулированием твердого стока рек и неконтролируемой добычей песка с пляжей и подводного склона, необоснованным гидротехническим и берегозащитным строительством, загрязнением морских вод и донных осадков.

Сегодня основным источником пляжеобразующего материала в береговой зоне являются продукты размыва берегов и подводного берегового склона, однако их количества недостаточно для полного насыщения Каламитского вдольберегового потока наносов. Сложившийся дефицит обломочного материала компенсируется за счет сокращения ширины пляжей и истощения запасов пляжевых накоплений, отступания берегов, размыва отложений подводного склона и реликтовых гравийно-галечных глубоководных валов, переуглубления приурезовой зоны. В результате, по наблюдениям с начала XX в. ширина пляжей на разных участках Каламитского залива сократилась в 2-4 раза, а средние скорости размыва берегов составили 1,3 м.год ${ }^{-1}$.

Для сохранения пляжей Евпатории и Сакской пересыпи актуальна реализация научно и технически обоснованных проектов берегозащиты.

\section{СПИСОК ЛИТЕРАТУРЫ}

1. Агаркова И. В. Влияние хозяйственной деятельности на динамику Сакского побережья // Ученые записки Таврического национального университете им. В. И. Вернадского. Серия «География», 1999, 12 (51), № 1, с. 15-19.

2. Агаркова-Лях И. В. Антропогенные и природные факторы сокращения Сакских пляжей // Записки общества геоэкологов, 2007, вып. 9, с. 24-30.

3. Агаркова-Лях И. В. Современное состояние пляжей Западного побережья Крыма и актуальные вопросы берегового природопользования // Экологическая безопасность прибрежной и шельфовой зон и комплексное использование ресурсов шельфа, 2014, вып. 29 , с. $50-60$.

4. Агаркова-Лях И.В., Скребец Г.Н. Ландшафты береговой зоны Черного моря // Современные ландшафты Крыма и сопредельных акваторий, 2009, с. 250-279.
5. Болтачева Н.А., Мильчакова Н.А., Миронова Н. В. Изменения бентоса в районе Каламитского залива под влиянием эвтрофирования // Экология моря, 1999, вып. 49, с. 5-9.

6. Горячкин Ю.Н. Берегозащитные сооружения Крыма: Западное побережье // Гидротехника, 2016, № 1, c. 49-54.

7. Горячкин Ю.Н. Берегозащитные сооружения Крыма: Западное побережье // Гидротехника, 2016, № 2, c. 38-43.

8. Гуров К.И. Результаты мониторинга динамики береговой зоны и гранулометрического состава наносов пляжей в центральной части Каламитского залива // Экологическая безопасность прибрежной и шельфовой зон моря, 2020, №1, с. 36-46. DOI:10.22449/24135577-2020-1-36-46

9. Долотов В.В., Иванов В.А. Повышение рекреационного потенциала Украины: кадастровая оценка пляжей Крыма. Севастополь: МГИ НАНУ, 2007. 194 с.

10. Иванов В.А., Ястреб В.П., Горячкин Ю.Н., Прусов А.В., Зима В.В., Фомин В.В. Природопользование на черноморском побережье Западного Крыма: современное состояние и перспективы развития / Под ред. В.А. Иванова. Севастополь: ЭКОСИ-Гидрофизика, 2006. $324 \mathrm{c}$.

11. Игнатов Е.И., Орлова М.С., Санин А.Ю. Береговые морфосистемы Крыма. Севастополь: ЭКОСИ-Гидрофизика, 2014. 266 с.

12. Клюкин А. А. Экзогеодинамика Крыма. Симферополь: Таврия, 2007. $320 \mathrm{c}$.

13. Махаева Т.В. К геоморфологии и динамике берегов Западного Крыма // Геология побережья и дна Черного и Азовского морей в пределах УССР, 1968, вып. 2, с. 160-165.

14. Прогноз экзогенных геологических процессов на черноморском побережье СССР / Под ред. А.И. Шеко, В. С. Круподерова. Москва: Недра, 1979. 239 с.

15. Современное состояние береговой зоны Крыма: атлас-монография / Под ред. Ю.Н. Горячкина. Севастополь: ЭКОСИ-Гидрофизика, 2015. 252 с.

16. Удовик В.Ф., Горячкин Ю.Н. Межгодовая изменчивость вдольберегового потока наносов в береговой зоне Западного Крыма // Экологическая безопасность прибрежной и шельфовой зон и комплексное использование ресурсов шельфа, 2013, вып. 27, c. $363-368$.

17. Шуйский Ю.Д. Механический состав пляжевых наносов на западных берегах Крымского полуострова // Экологическая безопасность прибрежной и шельфовой зон и комплексное использование ресурсов шельфа, 2007, вып. 15, с. 370-375.

18. Шуйский Ю.Д. Основные закономерности морфологии и динамики Западного берега Крымского полуострова // Экологическая безопасность прибрежной и шельфовой зон и комплексное использование ресурсов шельфа, 2005, вып. 13, с. 62-72.

19. Шуйский Ю.Д. Питание обломочным материалом северо-западного и крымского районов шельфа 
Черного моря // Исследование динамики рельефа морских побережий, 1979, с. 89-97.

20. Шуйский Ю. Д. Процессы и скорости абразии на украинских берегах Черного и Азовского морей // Известия АН СССР. Серия география, 1974, №6, с. 108-117.

21. Шуйський Ю.Д. Типи берегів Світового океану. Одесса: Астропринт, 2000. 480 с.

22. Rubtsova S., Agarkova-Lyakh I., Lyamina N., Lyamin A. Modern state and dynamic of the beaches of Kalamitskiy gulf in the Western Crimea // Managing risks to coastal regions and communities in a changing world. EMECS'11-SeaCoasts XXVI. Proceedings of International Conference. August 22-27, 2016. St. Petersburg, Russia. pp. 644-652.

Конфликт интересов: Авторы декларируют отсутствие явных и потенциальных конфликтов интересов, связанных с публикацией настоящей статьи.

Поступила в редакичию 17.09.2020 Принята к публикации 03.09.2021

UDC [551.435.3+551.351+551.35.054](262.5)

ISSN 1609-0683

DOI: https://doi.org/10.17308/geo.2021.3/3599

\title{
Multiyear Trend of Beaches and Coasts of the Kalamitsky Gulf of the Crimea
}

\author{
I.V. Agarkova-Lyakh ${ }^{1 凶}$, A. M. Lyakh ${ }^{2}$ \\ ${ }^{1}$ Institute of natural and technical systems, Russian Federation \\ (28, Lenina str., Sevastopol, 299011) \\ ${ }^{2} A$. O. Kovalevsky Institute of Biology of the Southern Seas of RAS, Russian Federation \\ (2, Nakhimov Ave., Sevastopol, 299011)
}

\begin{abstract}
The aim of the work is to characterize the dynamics of beaches and coasts of the Kalamitsky Gulf according to long-term observations data for the period of the twentieth-early twentyfirst centuries.

Methods. To analyze the available information, we used comparative-geographical, comparative-historical and cartographical research methods. During the coastal research we used a complex of field methods: observation in the key sectors, instrumental and semi-instrumental measuring, photo-methods.

Results. The changes in beaches width in the borders of Evpatoriya (since the beginning of twenty century) and on the other parts of the gulf (since the mid-80th of twenty-century) were considered. Velocities of the coastal recession have been characterized according to the observations since the 40s of the twenty century. The anthropogenic and natural factors determining the modern coastal dynamics were indicated.

Conclusions. During the considered period, the beach width in different parts of the Kalamitsky Gulf decreased by 2-4 times, and in some parts the beaches disappeared completely. During the last 100 years the average rate of coastal erosion was $1.3 \mathrm{~m} \cdot \mathrm{year}^{-1}$, the maximum was $7.8 \mathrm{~m} \cdot \mathrm{year}{ }^{-1}$. These processes are accompanied by depletion of debris stocks on the beach and the submarine slope, erosion of bench deposits, destruction of the coastal constructions. This situation is caused by the shortage of clastic material in the coastal zone caused by intensive economic activity on the coast: quarries, creation of water reservoirs, hydraulic engineering and coastal protection construction, water area pollution and bottom sediments. Natural factors play a subordinate role in beach degradation like sea level rise, coastal sinking, coastal lithology, sediments attrition, aeolian outflow, changes in wind-wave conditions, and activation of extreme storms.
\end{abstract}

Key words: beaches width reduction, coastal and benches erosion, receding coastline, debris scarcity, economics activity.

(C) Agarkova-Lyakh I. V., Lyakh A. M., 2021

$\triangle$ Irina V. Agarkova-Lyakh, e-mail: iva_crimea@mail.ru

The content is available under Creative Commons Attribution 4.0 License.

Вестник ВГУ, Серия: География. Геоэкология, 2021, № 3, 41-51 


\section{V. Agarkova-Lyakh, A. M. Lyakh}

Funding: The study was supported by state assignment of Institute of natural and technical Systems (Project Reg. No. AAAA-A19-119031490078-9) and IBSS (state registration No. AAAA-A18-118020890074-2).

For citation: Agarkova-Lyakh I.V., Lyakh A.M. Multiyear Trend of Beaches and Coasts of the Kalamitsky Gulf of the Crimea. Vestnik Voronezskogo gosudarstvennogo universiteta. Geografia geoekologia, 2021, no. 3, pp. 41-51. (In Russ.) DOI: https://doi.org/10.17308/geo.2021.3/3599

\section{REFERENCES}

1. Agarkova I. V. Vliyanie khozyaystvennoy deyatel'nosti na dinamiku Sakskogo poberezh'ya [Influence of economic activity on the dynamics of the Saky coast]. Uchenye zapiski Tavricheskogo nacional'nogo universiteta im. V.I. Vernadskogo. Seria «Geografia», 1999, v. 12 (51), no. 1, pp. 15-19. (in Russ.)

2. Agarkova-Lyakh I. V. Antropogennye i prirodnye faktory sokrashcheniya Sakskikh plyazhey [Anthropogenic and natural factors of Saky beaches reduction]. Zapiski obshchestva geoekologov, 2007, v. 9, pp. 24-30. (in Russ.)

3. Agarkova-Lyakh I.V. Sovremennoe sostoyanie plyazhey Zapadnogo poberezh'ya Kryma i aktual'nye voprosy beregovogo prirodopol'zovaniya [Modern state of the beaches of the West Coast of Crimea and actual questions of coast using]. Ekologicheskaya bezopasnost' pribrezhnoy i shel'fovoy zon i kompleksnoe ispol'zovanie resursov shel'fa, 2014, v. 29, pp. 50-60. (in Russ.)

4. Agarkova-Lyakh I. V., Skrebets G.N. Landshafty beregovoy zony Chernogo morya [Landscapes of the coastal zone of the Black Sea]. Sovremennye landshafty Kryma i sopredel'nykh akvatoriy, 2009, pp. 250-279. (in Russ.)

5. Boltacheva N.A., Mil'chakova N.A., Mironova N.V. Izmeneniya bentosa $\mathrm{v}$ rayone Kalamitskogo zaliva pod vliyaniem evtrofirovaniya [Changes in benthos near the Gulf Kalamitsky under the influence of eutrophication of the sea]. Ekologiya morya, 1999, v. 49, pp. 5-9. (in Russ.)

6. Goryachkin Yu. N. Beregozashchitnye sooruzheniya Kryma: Zapadnoe poberezh'e [Coastal protection structures of the Crimea: West coast]. Gidrotekhnika, 2016, no. 1, pp. 49-54. (in Russ.)

7. Goryachkin Yu. N. Beregozashchitnye sooruzheniya Kryma: Zapadnoe poberezh'e [Coastal protection structures of the Crimea: West coast]. Gidrotekhnika, 2016, no. 2, pp. 38-43. (in Russ.)

8. Gurov K. I. Rezul'taty monitoringa dinamiki beregovoy zony i granulometricheskogo sostava nanosov plyazhey v tsentral'noy chasti Kalamitskogo zaliva [Results of monitoring the dynamics of the coastal zone and the granulometric composition of beach sediments in the central part of the Gulf of Kalamita]. Ekologicheskaya bezopasnost' pribrezhnoy i shel'fovoy zon morya, 2020, no. 1, pp. 36-46. (in Russ.) DOI:10.22449/24135577-2020-1-36-46

9. Dolotov V.V., Ivanov V.A. Povyshenie rekreacionnogo potenciala Ukrainy: kadastrovaja ocenka pljazhej Kryma [Increase in recreational capacity of Ukraine: cadastral assessment of beaches of the Crimea]. Sevastopol: MGI NANU, 2007, 194 p. (in Russ.)

10. Ivanov V.A., Yastreb V.P., Goryachkin Yu. N., Prusov A.V., Zima V.V., Fomin V.V. Prirodopol'zovanie na chernomorskom poberezh'e Zapadnogo Kryma: sovremennoe sostoyanie i perspektivy razvitiya [Nature management on the black sea coast of the Western Crimea: current state and development prospects]. Pod red. V.A. Ivanova. Sevastopol: EKOSI-Gidrofizika, 2006. 324 p. (in Russ.)

11. Ignatov E.I., Orlova M.S., Sanin A. Yu. Beregovye morfosistemy Kryma [Coastal morfosistems of the Crimea]. Sevastopol: EKOSI-Gidrofizika, 2014, 266 p. (in Russ.)

12. Klyukin A.A. Ekzogeodinamika Kryma [Ekzogeodinamik of the Crimea]. Simferopol: Tavriya, 2007, 320 p. (in Russ.)

13. Makhaeva T. V. K geomorfologii i dinamike beregov Zapadnogo Kryma [To geomorphology and dynamics of the coast of the Western Crimea]. Geologiya poberezh'ya $i$ dna Chernogo i Azovskogo morej v predelah USSR, pp. 160-165. (in Russ.)

14. Prognoz ekzogennykh geologicheskikh protsessov na chernomorskom poberezh'e SSSR [The forecast of exogenous geological processes on the Black Sea coast of the USSR]. Pod red. A. I. Sheko, V. S. Krupoderova. Moskow: Nedra, 1979. 239 p. (in Russ.)

15. Sovremennoe sostoyanie beregovoy zony Kryma: atlas-monografiya [Current state of a coastal zone of the Crimea: atlas-monograph.]. Pod red. Yu. N. Goryachkina. Sevastopol: EKOSI-Gidrofizika, 2015, 252 p. (in Russ.)

16. Udovik V.F., Goryachkin Yu.N. Mezhgodovaya izmenchivost' vdol'beregovogo potoka nanosov $\mathrm{v}$ beregovoy zone Zapadnogo Kryma [Interannual variability of longshore sediment flow in the coastal zone of the Western Crimea]. Ekologicheskaya bezopasnost' pribrezhnoy $i$ shel'fovoy zon i kompleksnoe ispol'zovanie resursov shel'fa, 2013, v. 27, pp. 363-368.

17. Shuyskiy Yu.D. Mekhanicheskiy sostav plyazhevykh nanosov na zapadnykh beregakh Krymskogo poluostrova [Mechanical Composition of Beach Alluvium on West Coast of the Crimea]. Ekologicheskaya bezopasnost' pribrezhnoy i shel'fovoy zon i kompleksnoe ispol'zovanie resursov shel'fa, 2007, v. 15. pp. 370-375 (in Russ.)

18. Shuyskiy Yu. D. Osnovnye zakonomernosti morfologii i dinamiki Zapadnogo berega Krymskogo poluostrova [Main regularities of morphology and dynamics of the Western coast of the Crimean Peninsula]. Ekologicheskaya bezopasnost' pribrezhnoy $i$ shel'fovoy zon $i$ kompleksnoe ispol'zovanie resursov shel'fa, 2005, v. 13. pp. 62-72. (in Russ.)

19. Shuyskiy Yu. D. Pitanie oblomochnym materialom severo-zapadnogo i krymskogo rayonov shel'fa Chernogo morya [Food detrital material of northwest and Crimean districts of the shelf of the Black Sea]. Issledovanie dinamiki rel'efa morskikh poberezhiy, 1979. pp. 89-97. (in Russ.) 
20. Shuyskiy Yu.D. Protsessy i skorosti abrazii na ukrainskikh beregakh Chernogo i Azovskogo morey [Processes and speeds of abrasion on the Ukrainian coast of the Black and Azov seas]. Izvestiya AN SSSR. Seriya geografiya, 1974, no. 6, pp. 108-117. (in Russ.)

21. Shuyskiy Yu.D. Tipi beregiv Svitovogo okeanu [Types of coast of the World Ocean]. Odessa: Astroprint, 2000, 480 p. (in Ukr.)

22. Rubtsova S., Agarkova-Lyakh I., Lyamina N., Lyamin A. Modern state and dynamic of the beaches of Kalamitskiy gulf in the Western Crimea. Managing risks

Агаркова-Лях Ирина Владимировна

кандидат географических наук, доцент, старший научный сотрудник лаборатории экологических проблем природопользования, Институт природно-технических систем, г. Севастополь, Российская Федерация, ORCID: 0000-0001-8471-2344, e-mail: iva_crimea@mail.ru

Лях Антон Михайлович

кандидат биологических наук, старший научный сотрудник отдела экологической паразитологии, Федеральное государственное бюджетное учреждение науки Федеральный исследовательский центр «Институт биологии южных морей имени А.О. Ковалевского PAH», г. Севастополь, Российская Федерация, ORCID: 0000-0001-7698-3961, e-mail: me@antonlyakh.ru to coastal regions and communities in a changing world. EMECS'11-SeaCoasts XXVI. Proceedings of International Conference. August 22-27, 2016. St. Petersburg, Russia. pp. 644-652.

Conflict of interests: The authors declare no information of obvious and potential conflicts of interest related to the publication of this article.

Received: 17.09.2020 Accepted: 03.09.2021

Irina V. Agarkova-Lyakh

Cand. Sci. (Geogr.), Assoc. Prof., Senior Researcher of the Environmental Problems of Nature Management Laboratory; Institute of Natural and Technical Systems; Sevastopol, Russian Federation, ORCID: 0000-0001-84712344,iva_crimea@mail.ru

Anton M. Lyakh

Cand. Sci. (Biol.), Senior Researcher of the Department of Environmental Parasitology; Federal State Budgetary Scientific Institution Federal Research Centre "A.O. Kovalevsky Institute of Biology of Southern Seas, Russian Academy of Sciences"; Sevastopol, Russian Federation, ORCID: 0000-0001-7698-3961,me@antonlyakh.ru 